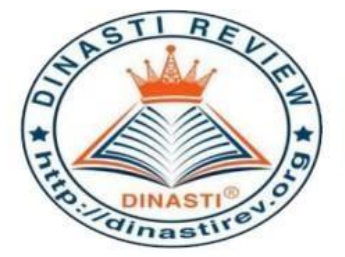

+62 878-9658-6407

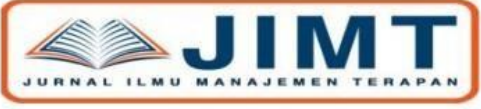

087896586407

https://dinastirev.org/JIMT editor@dinastirev.org

\title{
PENGARUH STRUKTUR MODAL, PERTUMBUHAN PERUSAHAAN DAN UKURAN PERUSAHAAN DENGAN PROFITABILITAS SEBAGAI VARIABEL INTERVENING TERHADAP NILAI PERUSAHAAN SEKTOR INFRASTRUKTUR DI BEI
}

\author{
Muliana $^{1}$, Khilyatin Ikhsani ${ }^{2}$ \\ ${ }^{1)}$ Universitas Mercu Buana, Jakarta \\ ${ }^{2)}$ Universitas Mercu Buana, Jakarta
}

ARTICLE INFORMATION

Received: 23 November 2019

Revised: 25 November 2019

Issued: 29 November 2019

Corresponding author: first author

E-mail:

muliana.pasca@gmail.com

khilyatin.ikhsnai@gmail.com

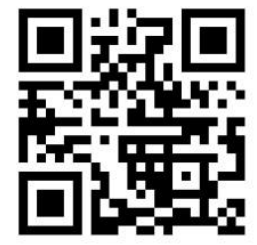

DOI:10.31933/JIMT

\begin{abstract}
Abstrak: Penelitian ini bertujuan untuk mengetahui kemampuan profitabilitas (diproksi dengan return on equity) dalam memediasi pengaruh struktur modal (diproksikan dengan debt to equity ratio), pertumbuhan perusahaan (diproksi dengan pertumbuhan penjualan), dan ukuran perusahaan (diproksi dengan logaritma natural total asset) terhadap nilai perusahaan. Populasi penelitian adalah sektor infrastruktur, utilitas, dan transportasi yang terdaftar di Bursa Efek Indonesia periode tahun 2013-2015. Metode penelitian menggunakan analisa jalur. Hasil penelitian menunjukkan Struktur modal dan pertumbuhan perusahaan berpengaruh positif dan tidak signifikan terhadap profitabiitas dan ukuran perusahaan berpengaruh negatif dan tidak signifikan terhadap profitabilitas. Struktur modal dan profitabilitas berpengaruh positif dan signifikan terhadap nilai perusahaan. Pertumbuhan perusahaan dan ukuran perusahaan berpengaruh negatif tidak signifikan terhadap nilai perusahaan. Profitabilitas tidak mampu memediasi pengaruh struktur modal, pertumbuhan perusahaan dan ukuran perusahaan terhadap nilai perusahaan.
\end{abstract}

Kata Kunci: Price Book Value, Return on Equity, Debt to Equity Ratio, Growth, dan Size.

\section{PENDAHULUAN}

Nilai perusahaan mencerminkan kinerja perusahaan yang dapat mempengaruhi persepsi investor terhadap perusahaan. Semakin tinggi nilai perusahaaan menggambarkan semakin sejahtera pemiliknya. 
Penilaian kinerja keuangan perusahaan sebagai akibat dari proses pengambilan keputusan manajemen, merupakan persoalan yang kompleks karena menyangkut efektivitas pemanfaatan modal dan efisiensi dari kegiatan perusahaan yang menyangkut nilai serta keamanan dari berbagai tuntutan yang timbul terhadap perusahaan. Perusahaan perlu melakukan analisis laporan keuangan, karena laporan keuangan merupakan salah satu alat yang digunakan untuk mengukur kinerja perusahaan. Laporan keuangan sebagai sumber informasi, akan lebih bermanfaat jika dilihat secara komperhensif misalnya dengan membandingkan suatu periode dengan periode yang lain. Salah satu cara pengukuran kinerja perusahaan dapat dilihat dari tingkat profitabilitasnya.

Tabel 1. Perbandingan ROE dan PBV Sektor Infrastructure, Utilities and Transportation, Property, Real Estate and Building Construction and Miscellaneous Industry Periode 2013-2015

\begin{tabular}{|c|c|c|c|c|c|c|c|}
\hline \multirow{2}{*}{ NO } & \multirow{2}{*}{ SEKTOR } & \multicolumn{3}{|c|}{ ROE (\%) } & \multicolumn{3}{|c|}{ PBV (Kali) } \\
\hline & & 2013 & 2014 & 2015 & 2013 & 2014 & 2015 \\
\hline 1. & $\begin{array}{l}\text { Infrastructure, } \\
\text { Utilities and } \\
\text { Transportation }\end{array}$ & 16.61 & 2.72 & 0.73 & 2.39 & 1.42 & 2.35 \\
\hline 2. & $\begin{array}{l}\text { Property, Real } \\
\text { Estate and Building } \\
\text { Construction }\end{array}$ & 11.94 & 11.00 & 6.29 & 1.88 & 2.37 & 2.04 \\
\hline 3. & $\begin{array}{l}\text { Miscellaneous } \\
\text { Industry }\end{array}$ & 13.62 & 14.44 & 14.10 & 0.94 & 1.12 & 1.23 \\
\hline
\end{tabular}

Sumber : IDX Statistik Tahunan (2013 - 2015)
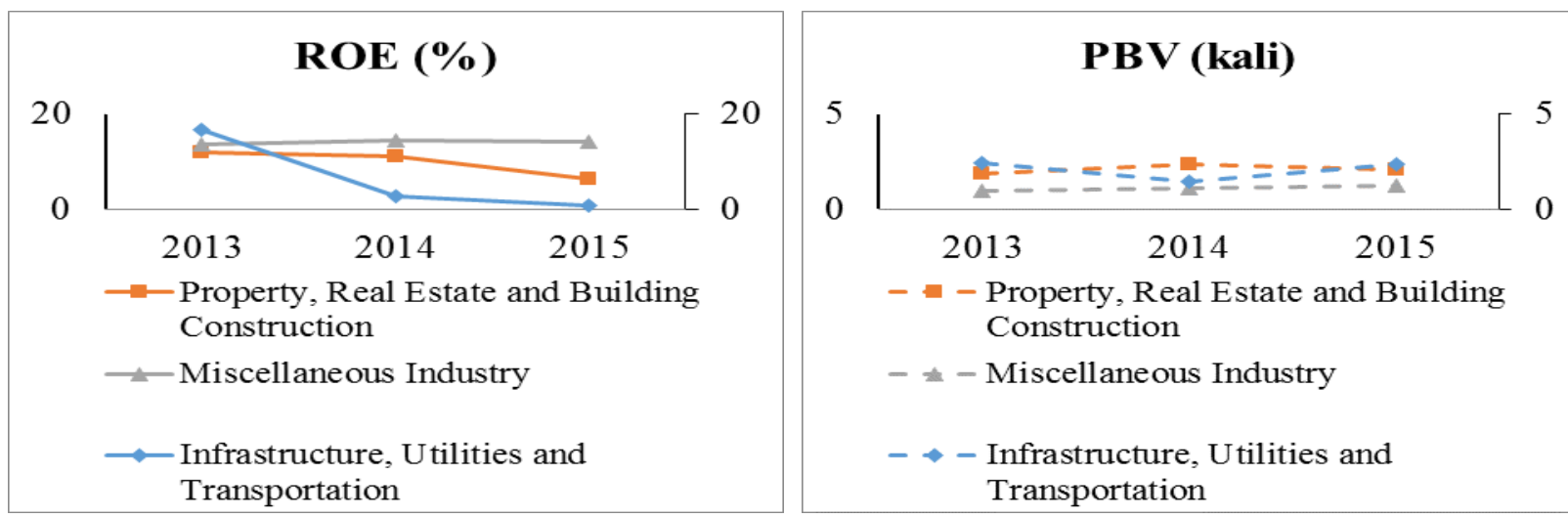

Gambar 1. ROE dan PBV Sektor Infrastructure, Utilities and Transportation, Property, Real Estate and Building Construction, and Miscellaneous Industry Periode 2013-2015 Sumber : IDX Statistik Tahunan (2013 - 2015)

Pada dasarnya kenaikan profitabilitas (ROE) akan diimbangi dengan kenaikan nilai perusahaan (PBV) dan penurunan ROE akan diimbangi dengan penurunan PBV. Penulis mencoba membandingkan secara random dengan sektor property, real estate and building construction dan sektor miscellaneous industry dilihat dari tabel 1 dan gambar 1 bahwa tidak ada pola yang baku antara ROE dan PBV. Ketika ROE sektor Infrastructure, Utilities and Transportation turun di tahun 2015, PBV sektor tersebut mengalami kenaikan. ROE sektor property, real estate and building construction turun di tahun 2014 sedangkan PBV 
mengalami kenaikan. Lain halnya dengan sektor miscellaneous industry naiknya ROE diringi dengan naiknya PBV di tahun 2014 kemudian flat. Karena fluktuasi ROE tidak memiliki format yang baku terhadap PBV kejadian ini menarik untuk diteliti.

Penelitian dalam hal ini dilakukan dengan mengambil sampel di tahun 2015 dikarenakan dimulainya kepemimpimpinan Presiden Joko Widodo melanjutkan kepemimpinan presiden Susilo Bambang Yudhoyono dimana masing-masing pemimpin fokus pada pembangunan infrastruktur Indonesia.

Debt to Equity Ratio (DER) sebagai proxy struktur modal dikarenakan DER mencerminkan besarnya proporsi antara total debt dan total shareholder's equity. Rasio ini menunjukkan komposisi dari total hutang terhadap total ekuitas. Semakin tinggi DER menunjukkan semakin besar kewajiban perusahaan terhadap pihak luar. Selanjutnya GROWTH dinyatakan sebagai pertumbuhan perusahaan dimana total penjualan masa lalu akan menggambarkan profitabilitas yang akan datang dan pertumbuhan yang akan datang. Pertumbuhan penjualan menggambarkan pertumbuhan perusahaan yang akan mempengaruhi profitabilitas perusahaan yang menyakini bahwa persentase perubahan penjualan merupakan indikator yang lebih baik dalam mengukur growth perusahaan. Ukuran perusahaan (SIZE) diukur dengan menghitung logaritma natural total asset.

Return of Equity (ROE) merupakan prorxy dari profitabiliatas. ROE menunjukkan keuntungan yang akan dinikmati oleh pemilik saham. Dalam peneltian ini ROE digunakan sebagai variabel intervening guna untuk mengetahui apakah profitabilitas dapat memperkuat atau memperlemah pengaruh struktur modal, pertumbuhan perusahaan, dan ukuran perusahaan terhadap nilai perusahaan melalui pengujian sobel. Profitabilitas selain digunakan sebagai variabel dependen dan independen juga dapat digunakan sebagai variabel intervening yang dapat memperkuat atau memperlemah pengaruh hubungan variabel independen terhadap variabel dependen, penilitan yang dilakukan oleh menurut Kusumajaya (2011) Profitabilitas mampu memperkuat hubungan struktur modal dan pertumbuhan perusahaan terhadap nilai perusahaan. Penelitian yang dilakukan oleh Hamidy (2015) menemukan bahwa profibilitas mampu memperkuat hubungan struktur modal terhadap nilai perusahaan.

Price Book Value (PBV) sebagai proxy dari nilai perusahaan karena PBV dianggap lebih melihat pada keadaan/kondisi sebenarnya dari sebuah perusahaan karena melihat dari sisi ekuitas/modal perusahaan.

\section{KAJIAN PUSTAKA}

\section{Teori Perusahaan (Theory of Frm)}

Tujuan utama perusahaan menurut theory of the firm adalah untuk memaksimumkan kekayaan atau nilai perusahaan (value of the firm) (Salvatore, 2005). Memaksimalkan nilai perusahaan sangat penting artinya bagi suatu perusahaan, karena dengan memaksimalkan nilai perusahaan berarti juga memaksimalkan kemakmuran pemegang saham yang merupakan tujuan utama perusahaan (Euis dan Taswan, 2002). Menurut Husnan (2000) nilai perusahaan merupakan harga yang bersedia dibayar oleh calon pembeli apabila perusahaan tersebut dijual. Sedangkan menurut Keown (2004) nilai perusahaan merupakan nilai pasar atas surat berharga hutang dan ekuitas perusahaan yang beredar.

\section{Teori Trade-off (Trade-off Theory)}

Trade-off theory telah mempertimbangkan berbagai faktor seperti corporate tax, biaya kebangkrutan, dan personal tax, dalam menjelaskan mengapa suatu perusahaan memilih 
struktur modal tertentu (Husnan, 2000). Kesimpulannya adalah penggunaan hutang akan meningkatkan nilai perusahaan tetapi hanya pada sampai titik tertentu. Setelah titik tersebut, penggunaan hutang justru menurunkan nilai perusahaan. Walaupun model trade-off theory tidak dapat menentukan secara tepat struktur modal yang optimal, namun model tersebut memberikan kontribusi penting yaitu;

1) Perusahaan yang memiliki aktiva yang tinggi, sebaiknya menggunakan sedikit hutang.

2) Perusahaan yang membayar pajak tinggi sebaiknya lebih banyak menggunakan hutang dibandingkan perusahaan yang membayar pajak

Peningkatan rasio utang pada stuktur modal akan meningkatkan nilai perusahaan.

\section{Teori Pensinyalan (Signaling Theory)}

Signaling theory menekankan kepada pentingnya informasi yang dikeluarkan oleh perusahaan terhadap keputusan investasi pihak di luar perusahaan. Informasi merupakan unsur penting bagi investor dan pelaku bisnis karena informasi pada hakekatnya menyajikan keterangan, catatan atau gambaran baik untuk keadaan masa lalu, saat ini maupun keadaan masa yang akan datang bagi kelangsungan hidup suatu perusahaan dan bagaimana pasaran efeknya. Informasi yang lengkap, relevan, akurat dan tepat waktu sangat diperlukan oleh investor di pasar modal sebagai alat analisis untuk mengambil keputusan investasi.

\section{Nilai Perusahaan}

Menurut Husnan (2000) dalam Safitri (2015 : 3) nilai perusahaan merupakan harga yang bersedia dibayar oleh calon pembeli apabila perusahaan tersebut dijual. Sedangkan menurut Keown (2004) nilai perusahaan merupakan nilai pasar atas surat berharga hutang dan ekuitas perusahaan yang beredar. Nilai perusahaan merupakan persepsi investor terhadap tingkat keberhasilan perusahaan yang sering dikaitkan dengan harga saham. Memaksimalkan nilai perusahaan sangat penting artinya bagi suatu perusahaan, karena dengan memaksimalkan nilai perusahaan berarti juga memaksimalkan kemakmuran pemegang saham yang merupakan tujuan perusahaan (Safitri, $2015: 3$ ).

\section{Struktur Modal}

Pada dasarnya, keputusan pendanaan (financing) perusahaan berkaitan dengan penentuan sumber-sumber dana yang digunakan untuk membiayai usulan usulan investasi yang telah diputuskan sebelumnya. Pemenuhan kebutuhan dana tersebut dapat disediakan atau diperoleh dari sumber internal maupun eksternal perusahaan. Apabila perusahaan memenuhi kebutuhan dananya dari sumber internal, maka perusahaan tersebut melakukan pendanaan internal (internal financing) yaitu dalam bentuk laba ditahan, sebaliknya, jika perusahan memenuhi kebutuhan dananya dari sumber eksternal, maka perusahaan tersebut melakukan pendanaan eksternal (external financing). Pemenuhan kebutuhan dana secara eksternal dipisahkan menjadi 2 yaitu pembiayaan utang (debt financing) dan pendanaan modal sendiri (equity financing). Pembiayaan utang diperoleh melalui pinjaman, sedangkan pendanaan modal sendiri berasal dari emisi atau penerbitan saham (Hamidy, 2014 : 25).

\section{Pertumbuhan Perusahaan (Growth)}

Safitri (2015 : 2) mengutip Tawan (2003) menjelaskan Pertumbuhan dinyatakan sebagai pertumbuhan total penjualan dimana pertumbuhan penjualan masa lalu akan menggambarkan profitabilitas yang akan datang dan pertumbuhan yang datang. Selanjutnya Saidi (2004) menjelaskan dalam safitri (2015 : 2) growth adalah perubahan (penurunan atau 
peningkatan) penjualan yang dimiliki oleh perusahaan. Pertumbuhan penjualan dihitung sebagai persentase perubahan penjualan pada saat tertentu terhadap tahun sebelumnya. Berdasarkan difinisi di atas dapat dijelaskan growth merupakan perubahan total penjualan baik berupa peningkatan maupun penurunan yang dialami oleh perusahaan selama satu periode (satu tahun).

\section{Ukuran Perusahaan}

Menurut Fidyati (2003) dalam Safitri (2015 : 3) Ukuran perusahaan secara langsung mencerminkan tinggi rendahnya aktivitas operasi suatu perusahaan. Pada umumnya semakin besar suatu perusahaan maka akan semakin besar pula aktivitasnya. Dengan demikian, ukuran perusahaan juga dapat dikaitkan dengan besarnya kekayaan yang dimiliki oleh perusahaan.

\section{Profitabilitas}

Profitabilitas merupakan kemampuan suatu perusahaan untuk mendapatkan laba (keuntungan) dalam suatu periode tertentu. Pengertian yang sama disampaikan oleh Husnan (2001) yang dikutip oleh Hermuningsih (2012 : 234) bahwa Profitabilitas adalah kemampuan suatu perusahaan dalam menghasilkan keuntungan (profit) pada tingkat penjualan, aset, dan modal saham tertentu. Profitabilitas menggambarkan kemampuan badan usaha untuk menghasilkan laba dengan menggunakan seluruh modal yang dimiliki. Profitabilitas suatu perusahaan akan mempengaruhi kebijakan para investor atas investasi yag dilakukan. Kemampuan perusahaan untuk menghasilkan laba akan dapat menarik para investor untuk menanamkan dananya guna memperluas usahanya, sebaliknya tingkat profitabilitas yang rendah akan menyebabkan para investor menarik dananya. Sedangkan bagi perusahaan itu sendiri profitabilitas dapat digunakan sebagai evaluasi atas efektivitas pengelolaan badan usaha tersebut.

\section{Hipotesis}

$\mathrm{H}_{1}$ : Struktur Modal berpengaruh terhadap profitabilitas.

$\mathrm{H}_{2}$ : Pertumbuhan perusahaan berpengaruh terhadap profitabilitas.

$\mathrm{H}_{3}$ : Ukuran perusahaan berpengaruh terhadap profitabilitas.

$\mathrm{H}_{4}$ : Struktur modal berpengaruh terhadap nilai perusahaan.

$\mathrm{H}_{5}$ : Pertumbuhan perusahaan berpengaruh terhadap nilai perusahaan.

$\mathrm{H}_{6}$ : Ukuran perusahaan berpengaruh terhadap nilai perusahaan.

$\mathrm{H}_{7}$ : Profitabilitas berpengaruh terhadap nilai perusahaan.

\section{METODE PENELITIAN}

\section{Design Penelitian}

Penelitian ini merupakan penelitian kausalitas dimana terdapat hubungan antara lima variabel. Hubungan dalam penelitian ini merupakan hubungan kausal yaitu sebab akibat, dimana ada variabel eksogen (bebas) yaitu variabel yang mempengaruhi variabel endogen (terikat) yaitu variabel yang dipengaruhi.

\section{Variabel Penelitian}

\section{1) Variabel Eksogen}

Variabel eksogen dalam model jalur adalah semua variabel yang tidak ada penyebabpenyebab eksplisitnya atau dalam diagram tidak ada anak-anak panah menuju ke arahnya, 
selain pada bagian kesalahan pengukuran. (Hamidy, 2014). Sruktur Modal (X1), Pertumbuhan Perusahaan (X2), Ukuran Perusahaan (X3) adalah variabel eksogen dari penelitian ini.

\section{2) Variabel Endogen}

Variabel endogen yang mencakup didalam penelitian adalah variabel perantara dan tergantung/terikat. Variabel perantara endogen adalah variabel yang dipengaruhi dan mempengaruhi dalam suatu model diagram jalur, dalam penelitian ini variabel perantara adalah Profitabilitas (Z), sedangkan variabel tergantung/terikat yaitu variabel yang merupakan akibat dari variabel yang mempengaruhi, yang dijadikan variabel tergantung/terikat adalah Nilai Perusahaan (Y).

Tabel 2. Variabel dan Pengukuran.

\begin{tabular}{ll}
\hline Variabel & Pengukuran Variabel \\
\hline Nilai Perusahaan $(\mathrm{Y})$ & $\mathrm{PBV}=\frac{\mathrm{Ps}}{\mathrm{BVS}}$ \\
\hline $\begin{array}{l}\text { Struktur Modal }(\mathrm{X} 1) \\
\begin{array}{l}\text { Pertumbuhan Perusahaan } \\
(\mathrm{X} 2)\end{array}\end{array}$ & $\mathrm{DER}=\frac{\text { Total Hutang }}{\text { Total Ekuitas }} \times 100 \%$ \\
\hline Ukuran Perusahaan $(\mathrm{X} 3)$ & Size $=\mathrm{Ln}($ Total Asset $)$ \\
\hline Profitabilitas $(\mathrm{Z})$ & $\mathrm{ROE}=\frac{\text { Sales }_{\mathrm{t}}-\text { Sales }_{\mathrm{t}-1}}{\text { Sales }_{\mathrm{t}}} \times 100 \%$ \\
\hline
\end{tabular}

\section{Populasi}

Populasi yang digunakan dalam penelitian ini adalah laporan keuangan perusahaan infrastruktur, utilitas, dan transportasi di BEI tahun 2015.

\section{Sampel}

Kriteria Penarikan Sampel :

1) Perusahaan infrastruktur, utilitas, dan transportasi yang terdaftar secara terus-menerus di BEI selama periode Tahun 2015.

2) Perusahaan infrastruktur, utilitas, dan transportasi yang sahamnya diperdagangkan aktif yaitu apabila frekuensi perdagangan saham selama satu tahun minimal $300 \mathrm{kali}$ atau lebih, hal ini sesuai dengan Surat Edaran Bursa Efek Jakarta No. SE-03/BEJ/II$1 / 1994$.

3) Perusahaan infrastruktur, utilitas, dan transportasi yang memiliki laporan keuangan lengkap selama selama periode Tahun 2015.

4) Perusahaan infrastruktur, utilitas, dan transportasi yang memiliki DER positif selama selama periode Tahun 2015.

Berdasarkan kriteria-kriteria tersebut maka jumlah sampel dari penelitian ini dapat dijelaskan pada tabel dibawah ini : 
Tabel 3. Jumlah Sampel Berdasarkan Kriteria Penarikan Sampel

\begin{tabular}{lll}
\hline No & Kriteria Penyaringan Sampel & Jumlah \\
\hline 1. & $\begin{array}{l}\text { Perusahaan bergerak di sektor infrastruktur, utilitas, } \\
\text { dan transportasi pada periode 2015 }\end{array}$ & \\
\hline 2. & $\begin{array}{l}\text { Perusahaan infrastruktur, utilitas, dan transportasi yang } \\
\text { sahamnya tidak aktif diperdagangkan selama satu } \\
\text { tahun minimal 300 kali atau lebih. }\end{array}$ \\
\hline 3. & $\begin{array}{l}\text { Perusahaan infrastruktur, utilitas, dan transportasi yang } \\
\text { tidak menerbitkan laporan keuangan pada periode }\end{array}$ \\
& 2015. & \\
\hline 4. & $\begin{array}{l}\text { Perusahaan infrastruktur, utilitas, dan transportasi yang } \\
\text { memiliki DER positif selama selama periode Tahun }\end{array}$ \\
& 2015. & $\mathbf{2 6}$ \\
\hline & Jumlah sample penelitian & \\
\hline
\end{tabular}

\section{Metode Analisis Data}

Teknik dalam menganalisa data dalam penelitian ini menggunakan teknik estimasi path analysis untuk menguji pengaruh variabel intervening. Path analysis merupakan perluasan dari analisis regresi linear berganda, atau analisis jalur untuk menaksir hubungan kausalitas antar variabel.

\section{PEMBAHASAN}

\section{Evaluasi Terhadap Pemenuhan Asumsi Analisis Jalur}

Asumsi yang melandasi analisis jalur adalah:

1) Di dalam model analisis jalur hubungan antara variabel adalah linier dan aditif. Uji lineritas menggunakan curve fit dan menerapkan prinsip parsimony, yaitu bilamana seluruh model signifikan atau nonsignifikan, berarti dapat ditetapkan seluruh model berbentuk linier.

2) Hanya model rekursif dapat dipertimbangkan, model yang dibuat hanya sistem aliran kausal ke satu arah, tidak bolak-balik sehingga analisis jalur layak diterapkan.

3) Ukuran variabel endogen dan eksogen yang dianalisis berskala rasio. Oleh karena itu, analisis jalur layak digunakan dalam penelitian ini.

4) Model yang dianalisis diidentifikasi dengan benar berdasarkan teori-teori dan konsepkonsep yang relevan.

Tabel 4. Ringkasan Model Linier

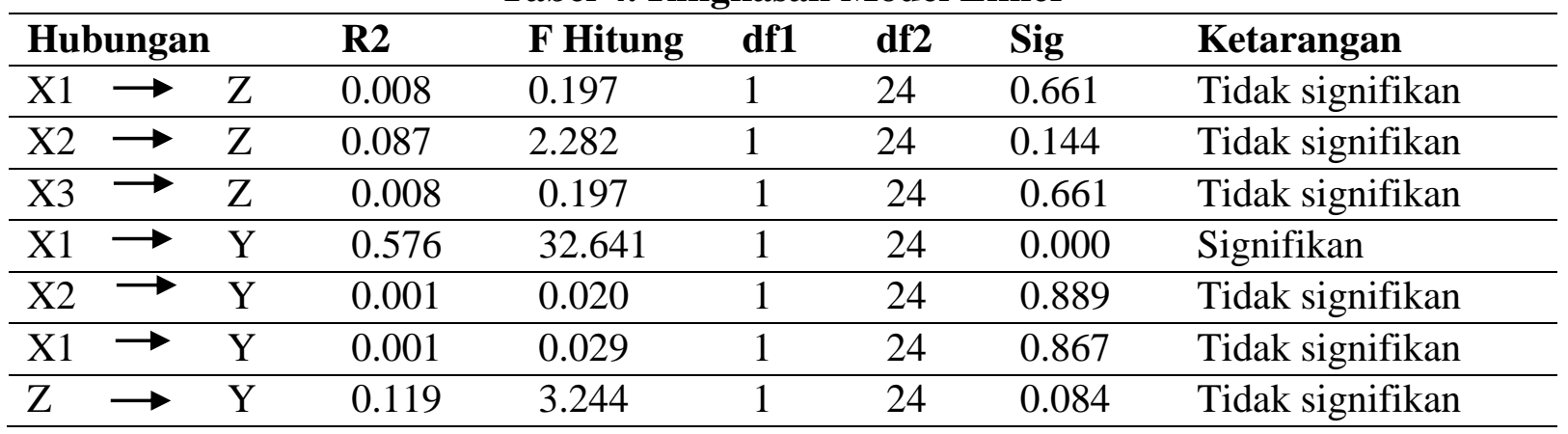

Sumber : data yang diolah 
Keterangan :

$\mathrm{X}_{1}=$ Struktur Modal

$\mathrm{X}_{2}=$ Pertumbuhan perusahaan

$\mathrm{X}_{3}=$ Ukuran Perusahaan

$\mathrm{Z}=$ Profitabilitas

$\mathrm{Y}=$ Nilai Perusahaan

\section{Evaluasi Terhadap Validitas Model}

Dalam menguji validitas model di dalam analisis jalur digunakan koefisien determinasi total, diukur dengan:

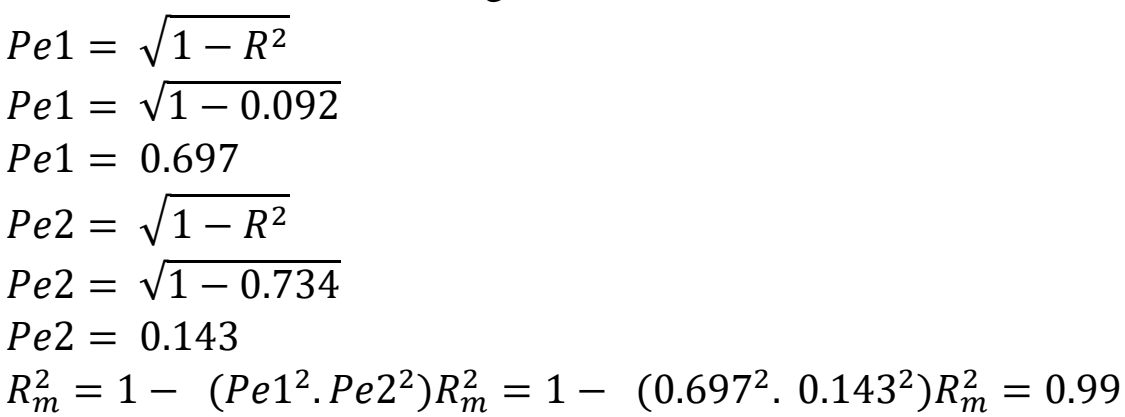

Koefisien determinasi total persamaan struktural dari model penelitian sesuai dengan perhitungan diperoleh nilai $\mathrm{R}^{2} \mathrm{~m}=0.09$. Koefisien determinasi total sebesar 0.09 mempunyai arti bahwa sebesar 99 persen informasi yang terkandung dapat dijelaskan oleh model yang dibentuk, sedangkan sisanya, yaitu 1 persen dijelaskan oleh variabel lain di luar model yang dibentuk. Pei merupakan standard error of estimate dari model regresi, $\mathrm{Pe} 1$ sebesar 0.697 dan $\mathrm{P} e 2$ sebesar 0.143.

\section{Koefisien Jalur}

Tabel 5. Ringkasan Koefisien Jalur

\begin{tabular}{|c|c|c|c|c|c|c|c|}
\hline \multicolumn{3}{|c|}{ Regresi } & $\begin{array}{l}\text { Koef. .Reg } \\
\text { Standar }\end{array}$ & $\begin{array}{l}\text { Standar } \\
\text { Error }\end{array}$ & t hitung & P Value & Keterangan \\
\hline $\mathrm{X} 1$ & $\rightarrow$ & $\mathrm{Z}$ & 0.038 & 0.031 & 0.175 & 0.862 & Tidak signifikan \\
\hline $\mathrm{X} 2$ & $\rightarrow$ & $\mathrm{Z}$ & 0.326 & 0.243 & 1.390 & 0.178 & Tidak signifikan \\
\hline X3 & $\longrightarrow$ & $\mathrm{Z}$ & -0.083 & 0.024 & -0.345 & 0.734 & Tidak signifikan \\
\hline $\mathrm{X} 1$ & $\rightarrow$ & $Y$ & 0.827 & 0.346 & 6.931 & 0.000 & Signifikan \\
\hline $\mathrm{X} 2$ & $\longrightarrow$ & $Y$ & -0.190 & 2.839 & -1.400 & 0.176 & Tidak signifikan \\
\hline X3 & $\longrightarrow$ & $Y$ & -0.166 & 0.271 & -1.246 & 0.227 & Tidak signifikan \\
\hline $\mathrm{Z}$ & $\longrightarrow$ & $Y$ & 0.341 & 2.384 & 2.892 & 0.009 & Signifikan \\
\hline
\end{tabular}

Sumber : Data yang diolah

Struktur modal (X1), pertumbuhan perusahaan (X2) berpengaruh positif dan tidak signifikan terhadap profitabilitas (Z). Sedangkan ukuran perusahaan (X3) berpengaruh negatif dan tidak signifikan.

Variabel struktur modal (X1) dan profitabilitas (Z) berpengaruh positif dan signifikan terhadap nilai perusahaan (Y). Pertumbuhan perusahaan (X2), dan ukuran perusahaan (X3) berpengaruh negatif dan tidak signifikan terhadap nilai perusahaan (Y). 


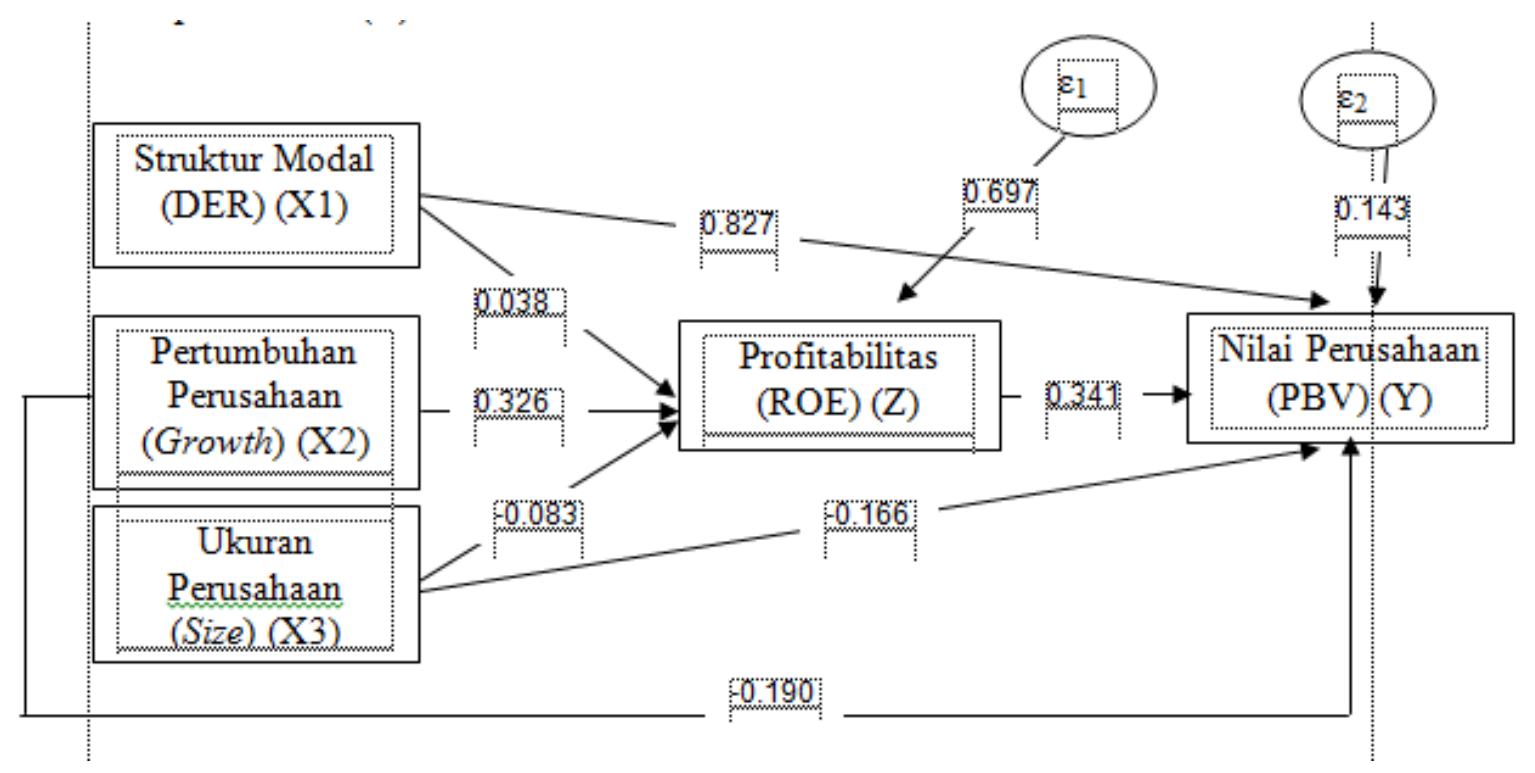

Gambar 2. Hasil Kofisien Diagram Jalur

Sumber : Data yang diolah

Persamaan Struktur I : $\mathbf{Z}=\mathbf{a}+\boldsymbol{\beta}_{1} \mathbf{X}_{\mathbf{1}}+\boldsymbol{\beta}_{\mathbf{2}} \mathbf{X}_{\mathbf{2}}+\boldsymbol{\beta}_{\mathbf{3}} \mathbf{X}_{\mathbf{3}+} \boldsymbol{\varepsilon}_{\mathbf{1}}$

ROE $=0.161+0.038 *$ DER+0.326*GROWTH-0.083*SIZE

Persamaan Struktur II : $\mathbf{Y}=\mathbf{a}+\boldsymbol{\beta}_{\mathbf{1}} \mathbf{X}_{\mathbf{1}}+\boldsymbol{\beta}_{\mathbf{2}} \mathbf{X}_{\mathbf{2}}+\boldsymbol{\beta}_{\mathbf{3}} \mathbf{X}_{\mathbf{3}}+\boldsymbol{\beta}_{\mathbf{4}} \mathbf{Z}+\boldsymbol{\varepsilon}_{\mathbf{2}}$

PBV $=3.221+0.827 *$ DER-0.190*GROWTH-0.166*SIZE+0.341*ROE

Gambar 2 merupakan koefisien hubungan langsung antar variabel. Pengaruh struktur modal (X1) terhadap profitabilitas (Z) positif dan tidak signifikan sebesar 0.038 , sedangkan pengaruh pertumbuhan perusahaan (X2) terhadap profitabilitas (Z) positif dan tidak signifikan sebesar 0.326 dan pengaruh ukuran perusahaan (X3) terhadap profitabilitas (Z) negatif tidak signifikan sebesar -0.083 .

Pengaruh struktur modal (X1) terhadap nilai perusahan (Y) positif dan signifikan sebesar 0.827, pengaruh pertumbuhan perusahaan (X2) terhadap nilai perusahaan (Y) negatif dan tidak signifikan sebesar -0.190 , pengaruh ukuran perusahaan (X3) terhadap nilai perusahaan (Y) negatif dan tidak signifikan sebesar -0,166. Sedangkan profitabilitas (Z) terhadap nilai perusahaan $(\mathrm{Y})$ berpengaruh positif dan signifikan terhadap nilai perusahaan (Y) sebesar 0.341 .

Dari gambar 2 dapat dihitung hubungan tidak langsung, berikut rekapitulasi hasil uji analisis path.

Tabel 6. Rekapitulasi Hasil Uji Analisis Path

\begin{tabular}{lll}
\hline No & Pengujian & Hasil Pegujian \\
\hline 1 & Pengaruh Langsung $\mathrm{X}_{1}$ ke $\mathrm{Y}$ & 0.827 \\
\hline & Pengaruh Tidak Langsung $\mathrm{X}_{1}$ ke $\mathrm{Z}$ ke $\mathrm{Y}$ & 0.28201 \\
\hline \multirow{2}{*}{2} & Total Pengaruh $\mathrm{X}_{1}$ ke $\mathrm{Y}$ & 1.10901 \\
\hline & Pengaruh Langsung $\mathrm{X}_{2}$ ke $\mathrm{Y}$ & -0.19 \\
\hline & Pengaruh Tidak Langsung $\mathrm{X}_{2}$ ke $\mathrm{Z}$ ke $\mathrm{Y}$ & -0.0648 \\
\hline \multirow{2}{*}{3} & Total Pengaruh $\mathrm{X}_{2}$ ke $\mathrm{Y}$ & -0.2548 \\
\hline
\end{tabular}




\begin{tabular}{lll}
\hline & Pengaruh Tidak Langsung $\mathrm{X}_{3}$ ke Z ke Y & 0.11628 \\
\hline & Total Pengaruh $\mathrm{X}_{3}$ ke $\mathrm{Y}$ & 0.45728 \\
\hline 4 & Pengaruh Langusng Z ke Y & 0.341 \\
\hline
\end{tabular}

Sumber : Data yang diolah

Tabel 7. Ringkasan Sobel Test

\begin{tabular}{lll}
\hline Test Result & $\boldsymbol{P}$ Value & Keterangan \\
\hline DER & 0.99020709 & Tidak ada pengaruh mediasi \\
\hline GROWTH & 0.18034814 & Tidak ada pengaruh mediasi \\
\hline SIZE & 0.97231048 & Tidak ada pengaruh mediasi \\
\hline
\end{tabular}

Sumber : Data yang diolah

\section{Pengujian Hipotesis dan Pembahasan}

$\mathrm{H}_{1}$ : Struktur Modal berpengaruh terhadap profitabilitas.

Koefisien regresi dari struktur modal terhadap profitabilitas adalah sebesar 0.038 dengan taraf signifikansi 0.862>0.050. Struktur modal berpengaruh positif dan tidak signifikan terhadap profitabilitas. Hasil penelitian ini berarti bahwa peningkatan dan penurunan pengambilan utang jangka panjang dalam struktur modal perusahaan tidak berpengaruh searah terhadap profitabilitas.

$\mathrm{H}_{2}$ : Pertumbuhan perusahaan berpengaruh terhadap profitabilitas.

Koefisien regresi dari pertumbuhan perusahaan terhadap profitabilitas adalah sebesar 0.326 dengan taraf signifikansi $0.178>0.050$. Pertumbuhan perusahaan berpengaruh positif dan tidak signifikan terhadap profitabilitas, berarti peningkatan pertumbuhan perusahaan yang diukur dengan pertumbuhan penjualan akan meningkatkan profitabilitas namun tidak signifikan.

\section{$\mathrm{H}_{3}$ : Ukuran perusahaan berpengaruh terhadap profitabilitas.}

Regresi dari ukuran perusahaan terhadap nilai perusahaan adalah sebesar -0.083 dengan taraf signifikansi $0.734>0.050$. Ukuran perusahaan berpengaruh negatif dan tidak signifikan terhadap nilai perusahaan, berarti ukuran perusahaan yang menggunakan logaritma natural total asset tidak dapat meningkatkan profitabilitas perusahaan.

Hasil penelitian ini menolak penelitian Sari (2014) dan Kusumajaya (2011) dimana hasil penelitian menunjukkan bahwa struktur modal, pertumbuhan perusahaan dan ukuran perusahaan berpengaruh positif dan signifikan terhadap profitabilitas.

\section{$\mathrm{H}_{4}$ : Struktur modal berpengaruh terhadap nilai perusahaan.}

Koefisien regresi dari struktur modal terhadap nilai perusahaan adalah sebesar 0.827 dengan taraf signifikansi $0.000<0.050$. Struktur modal berpengaruh positif dan signifikan terhadap nilai perusahaan, temuan ini didukung oleh tradeoff theory yang menyatakan bahwa (dengan asumsi titik target struktur modal yang belum optimal) peningkatan rasio utang pada stuktur modal akan meningkatkan nilai perusahaan. Struktur modal merupakan kunci perbaikan produktivitas dan kinerja perusahaan. Teori struktur modal menjelaskan bahwa kebijakan pendanaan (financial policy) perusahaan dalam menentukan struktur modal (bauran antara hutang dan ekuitas) bertujuan untuk mengoptimalkan nilai perusahaan (value of the firm).

$\mathbf{H}_{5}$ : Pertumbuhan perusahaan berpengaruh terhadap nilai perusahaan.

Koefisien regresi dari pertumbuhan perusahaan terhadap nilai perusahaan adalah sebesar -0.190 dengan taraf signifikansi 0.176>0.050. Pertumbuhan perusahaan berpengaruh 
negatif dan tidak signifikan terhadap nilai perusahaan. hal ini berarti pertumbuhan penjualan tidak mempengaruhi tinggi atau rendahnya nilai perusahaan.

\section{$\mathrm{H}_{6}$ : Ukuran perusahaan berpengaruh terhadap nilai perusahaan.}

Koefisien regresi dari pertumbuhan perusahaan terhadap nilai perusahaan adalah sebesar -0.166 dengan taraf signifikansi $0.227>0.050$. Ukuran perusahaan berpengaruh negatif dan tidak signifikan terhadap nilai perusahaan., berarti besar kecilnya perusahaan tidak mempengaruhi nilai perusahaan.

\section{$\mathbf{H}_{7}$ : Profitabilitas berpengaruh terhadap nilai perusahaan.}

Koefisien regresi dari profitabilitas terhadap nilai perusahaan adalah sebesar 0.341 dengan taraf signifikansi $0.009<0.050$. Profibilitas berpengaruh positif dan signifikan terhadap nilai perusahaan, berarti Return on equity (ROE) merupakan rasio yang menunjukkan kemampuan perusahaan dalam menghasilkan laba bersih untuk pengembalian ekuitas pemegang saham.

Hasil penelitian ini mendukung penelitian Kusumajaya (2011) dan Hamidy (2014) dimana hasil penelitian ini menunjukkan bahwa struktur modal dan profitabilitas perusahaan berpengaruh positif dan signifikan terhadap nilai perusahaan. Selain itu, penelitian ini mendukung penelitian Gultom, Agustina dan Wijaya (2013) dimana hasil penelitian ini menunjukkan bahwa pertumbuhan perusahaan dan ukuran perusahaan tidak berpengaruh signifikan terhadap nilai perusahaan.

\section{KESIMPULAN DAN SARAN \\ Kesimpulan}

Seperti yang telah dikemukakan pada bab terdahulu bahwa tujuan penelitian ini adalah untuk mengetahui pengaruh struktur modal, pertumbuhan perusahaan, dan ukuran perusahaan terhadap nilai perusahaan dengan profitabilitas sebagai variabel intervening pada perusahaan infrastruktur, utilitas dan transportasi yang terdaftar di BEI.

Berdasarkan hasil pengujian maka dapat disimpulkan sebagai berikut :

Dalam analisa jalur / path analysis menyimpulkan :

1) Struktur modal (DER) berpengaruh negatif dan tidak signifikan terhadap profitabilitas (ROE).

2) Pertumbuhan perusahaan (GROWTH) berpengaruh negatif dan tidak signifikan terhadap profitabilitas (ROE).

3) Ukuran perusahaan (SIZE) berpengaruh negatif dan tidak signifikan terhadap profitabilitas (ROE).

4) Struktur modal (DER) berpengaruh positif dan signifikan terhadap nilai perusahaan (PBV).

5) Pertumbuhan perusahaan (GROWTH) berpengaruh negatif dan tidak signifikan terhadap nilai perusahaan $(\mathrm{PBV})$.

6) Ukuran perusahaan (SIZE) berpengaruh negatif dan tidak signifikan terhadap nilai perusahaan (PBV).

7) Profitabilitas (ROE) berpengaruh positif dan signikan terhadap nilai perusahaan (PBV).

Dalam Sobel Test menyimpulkan bahwa Profitabilitas tidak berpengaruh signifikan dalam mengintervening pengaruh struktur modal, pertumbuhan perusahaan, dan ukuran perusahaan terhadap nilai perusahaan. 


\section{Saran}

1) Bagi perusahaan disarankan menjaga dan mengelola sumber daya yang dimiliki oleh perusahaan secara optimal. Selain itu sebagai manajer perusahaan perlu memperhatikan kinerja profitabilitas (ROE). Karena peningkatan profitabilitas mampu meningkatkan nilai perusahaan. Hasil menunjukkan ROE yang mempengaruhi PBV secara signifikan, sehingga ROE harus dijaga, karena paling dominan menjadi perhatian dan berpengaruh terhadap PBV adalahh ROE .

2) Bagi investor dalam memperhatikan nilai perusahaan sebaiknya dilihat dari sisi struktur modal dan ukuran perusahaan. Dalam penelitian ini variabel yang dapat digunakan asebagai acuan adalah DER dan SIZE.

Bagi penelitian selanjutnya untuk mendapatkan hasil penelitian yang kuat disarankan untuk menambahkan variabel lainnya, menggukan DER dan ROE yang positif, memperpanjang periode pengamatan dan menggunakan sektor lain sebagai objek penelitian.

\section{DAFTAR RUJUKAN}

Abbas, Ali dan Basir, Zahid. 2013. "Determinants of Firm's Financial Performance: An Empirical Study on Textile Sector of Pakistan". Business and Economic Research Vol. 3, No. 2, hal 76-86.

Afrianto, Dedy. 2016. OJK: Pasar Modal Jawaban Utama Pembangunan Infastruktur.http://economy.okezone.com/read/2016/09/19/320/1492678/ojk-pasarmodal-jawaban-utama-pembangunan-infrastruktur (Diakses tanggal 19 September 2016).

Akbar, Challahhu. 2014. Saham Infrastruktur Property Akan Terus Meningkat di Tahun 2014. http://challahhuakbar.blogspot.co.id/2014/12/saham-infrastruktur-propertiakan-terus.html. (Diakses 23 Desember 2014).

Amyulianthy, Rafrini dan Asriyal. 2013. Pengujian Empiris Efficient Market Hypothesis (EMH) dan Capital Asset Pricing Model (CAPM”. Jurnal Liquidity, Vol 2, No. 1, hal 21-33.

Anung, Wendyartaka. 2016. Pembangunan Infrastruktur dan Kesejahteraan. http://print.kompas.com/baca/opini/duduk-perkara/2016/06/01/Pembangunan-

Infrastruktur-dan-Kesejahteraan. (Diakses 1 juni 2015).

Ayako, Aloys dan Wamalwa, Fidelis. 2015. "Determinant of Firm Value in Kenya : Case of Commercial Banks Listed at the Nairobi Securities Exchange" Applied Finance and Accounting. Vol. 1, No. 2, hal 129-142.

Ayu, Sri Mahatma dan Wirajaya, Ary. 2013." Pengaruh struktur modal, profitabilitas dan ukuran perusahaan pada nilai perusahaan". E-Jurnal Akuntansi Universitas Udayana, Vol. 4.2, hal 358-372.

Brigham F., dan J. Houston. 2006. Dasar-Dasar Manajemen Keuangan. Penerjemah Ali Akbar Yulianto. Edisi Kesepuluh. Edisi Indonesia. Buku I. Salemba Empat. Jakarta.

Chen, Li-Ju dan Chen, Shun-Yu. 2011. "The Influence of Profitability on Firm Value With Capital Structure as The Mediator and Firm Size And Industry As Moderators". Investment Management and Financial Innovations, Vol. 8, Issue 3, hal 121 - 129.

Deil, Siska Amelie. 2015. Investor Masih Tergila-gila dengan Sektor Saham Infrastruktur RI. http://bisnis.liputan6.com/read/2188583/investor-masih-tergila-gila-dengan-sektorsaham-infrastruktur-ri. (Diakses 10 Maret 2015). 
Faizatur R., Suhadak, dan Darminto. 2013. "Pengaruh Struktur Modal Terhadap Profitabilitas (Studi Pada Perusahaan Real Estate And Property Yang Terdaftar Di Bursa Efek Indonesia (BEI) Periode 2009 - 2011)" Jurnal Universitas Brawijaya Malang, hal 111.

Ghozali, Imam. 2011. Aplikasi Analisis Multivariate Dengan Program IBM SPSS 19. Edisi 5. Universitas Diponegoro. Semarang.

2013. Aplikasi Analisis Multivariate Dengan Program IBM SPSS 23. Edisi 8.

Universitas Diponegoro. Semarang.

Gultom, Robinhot Agustina, dan Wijaya, Sri Widia. 2013. "Analisis Faktor-Faktor yang Mempengaruhi Nilai Perusahaan Pada Perusahaan Farmasi Di Bursa Efek Indonesia”. Jurnal Wira Ekonomi Mikroskil. Vol. 3, No. 01, hal 51-60.

Hamidy, Rahman Rusdi. 2014. "Pengaruh Struktur Modal Terhadap Nilai Perusahaan Dengan Profitabilitas Sebagai Variabel Intervening Pada Perusahaan Properti Dan Real Estate Di Bursa Efek Indonesia". Tesis. Program Studi Manajemen, Program Pascasarjana Universitas Udayana. Bali.

Hermuningsih, Sri. 2012. "Pengaruh Profitabilitas, Size Terhadap Nilai Perusahaan Dengan Sruktur Modal Sebagai Variabel Intervening”. Jurnal Siasat Bisnis. Vol. 16, No. 2, hal 232-242.

Idode, Patrick E., Adeleke, Toyoin M., Ogunlowore, Akindele J., Samuel Ashogbon Oyekan S.. 2014. "Influence of Capital Structure on Profitability : Empirical Evidence from listed Nigerian Banks”. IOSR Journal oof Business and Managemen (IOOSR-JBM). Vol. 16, Issue 11, Ver. IV, hal 22-28.

Indrawan, I Made. 2016. “Analisis Pengaruh EPS, DER, Size Firm Terhadap DPR dengan ROA sebagai variabel Intervening Pada Perusahaan Sektor Manufaktur di BEI tahun 2010-2015". Tesis. Program Studi Manajemen, Program Pasca Sarjana Universitas Mercu Buana. Jakarta.

John, Akinyomi Oladele dan Adebayo, Olagunju. 2013. "Effect of Firm Size on Profitability:

Evidence from Nigerian Manufacturing Sector". Prime Journal of Business Administration and Management ISSN: 2251-1261. Vol. 3, No. 9, hal 1171-1175.

Kartikasari, Dwi dan Marisa, Merianti. 2016. "The Effect Of Leverage and Firm Size to Profitability of Public Manufacturing Companies In Indonesia". International Journal of Economics and Financial Issues". Vol. 6, No. 2, hal 409-413.

Kusumajaya, Dewa Kadek Oka. 2011. "Pengaruh Struktur Modal dan Pertumbuhan Perusahaan Terhadap Profitabilitas dan Nilai Perusahaan Pada Perusahaan Manufaktur di Bursa Efek Indonesia" Tesis. Program Studi Manajemen, Program Pascasarjana Universitas Udayana. Bali.

Mule, Robert K., Suleiman M., Mukras, Nzioka, Mutunga O. 2015. "Corporate Size, Profitability and Market Value: an Econometric Panel Analysis of listed firms in Kenya". European Scientific Journal edition, Vol.11, No.13 ISSN: 1857 - 7881, hal 376-396.

Munawaroh, Aisyatul dan Priyadi, Maswar Patuh. 2014. "Pengaruh Profitabilitas Terhadap Nilai Perusahaan Dengan Corporate Social Responsibilty Sebagai Variabel Moderating”. Jurnal Ilmu \& Riset Akuntansi. Vol. 3, No. 4. hal 1-17.

Nasimi, Assad Naim. 2016. Effect of Capital Structure of Firm Profitability (An Empirical Evidence from London, UK)".Global Journal of Management and Business Research : C Finance. Vol. 16 Issue 4 Version 1.0, hal 1-13. 
Negasa, Tariku. 2016. “The Effect of Capital Structure on Firms' Profitability (Evidenced from Ethiopian)" Preprints, hal 1-9.

Niresh, J. Aloy dan Velnampy, T.. 2014. "Firm Size and Profitability: A Study of Listed Manufacturing Firms in Sri Lanka". International Journal of Business and Management; Vol. 9, No. 4, hal 57-64.

Pervan, Maja dan Visic, Josipa. 2012. "Influence of Firm Size on Its Business Success". Croatian Operational Research Review, Vol. 3, hal 213-223.

Pratama, Wira I. dan Wirawati, Ni G. 2016. "Pengaruh Struktur Modal dan Profitabilitas Terhadap Nilai Perusahaan dengan Kepemilikan Manajerial Sebagai Pemoderasi”. EJurnal Akuntansi Universitas Udayana. Vol. 15.3, hal 1796-1825.

Ramadan, Imad Zeyad. 2016. "Panel Data Approach of the Firm's Value Determinants: Evidence from the Jordanian Industrial Firms". Modern Applied Science, Vol. 10, No. 5, hal 163-169.

Regina R., Maryam M., dan Jacky SB. 2015. "Pengaruh Struktur Modal, Ukuran Perusahaan Dan Risiko Perusahaan Terhadap Nilai Perusahaan Pada Sub Sektor Plastik Dan Pengemasan Di BEI". Jurnal EMBA 159. Vol.3 No.3, hal 159-169.

Riduan dan Kuncoro. (2012). Cara Menggunakan dan Memakai Path Analysis (Analisis Jalur). Alfabeta. Bandung.

Rifai M., Rina A., dan Maria M. 2015. "Pengaruh Ukuran Perusahaan, Struktur Modal, dan Pertumbuhan Perusahaan terhadap Profitabilitas Studi pada Perusahaan Manufaktur di Bursa Efek Indonesia tahun 2010-2012”. Jurnal Universitas Pandanaran Semarang, hal 1-8.

Safitri, Hazlina dan Suwitho. 2015. "Pengaruh Size, Growth, dengan Kebijakan Dividen Sebagai Variabel Moderating Terhadap Nilai Perusahaan”. Jurnal Ilmu dan Riset Manajemen, Vol. 4, No. 6, hal 1-15.

Sari, Putu Indah Purnama dan Abundanti, Nyoman. 2014. "Pengaruh Pertumbuhan Perusahaan dan Leverage Terhadap Profitabilitas dan Nilai Perusahaan" E-Jurnal Manajemen Universitas Udayana Vol. 3 No. 5 Tahun 2014, hal. 1427-1439.

Sarwono, Jonathan. 2006. Metode Penelitian Kuantitatif dan Kualitatif. Graha Ilmu. Yogyakarta.

Shinta M., Suhandak, dan Nila F. 2014 "The Influence Of Capital Structure on Profitability and Firm Value (A Study On Food And Beverage Companies Listed In Indonesia Stock Exchange 2010-2012 Period)". Jurnal Administrasi Bisnis (JAB). Vol. 7 No.2. hal 1-8.

Sunarto. 2009. "Teori Keagenan dan Manajemen Laba", Kajian Akuntansi, Vol. 1, No. 1, ISSN: 1979-4886, hal 13-28.

Uke M., Suhadak, Siti H., dan Solimun. 2014. "The Influence of Company Size and Capital Structure towards Liquidity, Corporate Performance and Firm Value, for Large and Small Group Companies" European Journal of Business and Management. Vol. 6, No. 18, hal 148-157.

Winarto, Jacinta. 2015. "The Determinants of Manufacturer Firm Value in Indonesia Stock Exchange". International Journal of Information, Business and Management, Vol. 7, No.4, hal 323-350.

Yuanita M., Budiyanto, dan Slamet R. 2016. "Influence of Capital Structure, Size and Growth on Profitability and Corporate Value. International Journal of business and finance management research". Blue print journal. Vol. 4, hal 80-101. 